UDC 81-119 165.194

DOI https://doi.org/10.32841/2409-1154.2020.44.38

\author{
Maslova S. B., \\ Candidate of Philological Sciences, \\ Associate Professor of the Department of Foreign Languages № 2 \\ National University "Odesa Law Academy"
}

\title{
PREDICATE SIGN OF ENGLISH PROPOSITION
}

Summary. The article provides the results of linguistic analysis of English Proposition Predicate revealing its semantic meanings as the basic concept of the Englishlanguage discourse explicit Proposition and as the most adequate and capable sign to code any human's thought/idea/ image. The deductive, inductive, discovery, heuristic methods have resulted in deducing the key three generalized in their meanings Main Verbs "TO DO"/ "TO BE"/ "TO HAVE", which are the basis of all the Predicate Verb Patterns/Models. Heuristics (greek heurisko - to find, to discover) is the science that studies the creative activity, the methods used in the process of discovery of the new ideas and in teaching. Heuristic methods allow speeding up the process of solving a problem. The purpose of Heuristics is to build models of the process of solving a new task. The generalized meanings of all the Main Verbs are Action and State: "TO DO" means Action; "TO BE" - State and "TO HAVE" has got two meanings Action/State. It's just the Predicate Verb Pattern/Model that is in the basis of any Proposition (Sentence) and that is the basic code of reproducing any human's thought/idea/image. The article reveals the actual minimum basic constructive sign of coding any person's thought and that is the explicit Predicate Verb Pattern and Predicate Verb Model according to the idea that a person cannot think a thought without the Predicate. And this minimum code corresponds to Combination of Words as one of the formal elements of the English-language discourse hierarchy. Any Predicate Verb Pattern and any Predicate Verb Model is built on the basis of the Infinitive construction, which is known as "Infinitivization". The Infinitivization goes back to the Infinitive in its simple and compound forms (Verb, Phrasal Verb and Complementation Structure) and it may be regarded as "nucleus" of the potential Predicate Verb Pattern and Predicate Verb Model of the potential explicit Proposition. For instance, such constructions as Infinitivizations are widely presented in legal terminology and they represent the main part of its enormous database. Any legal term in the quality of the Infinitivization corresponds to a combination of words as a minimum sign/code of the English-language discourse. Infinitivization can be regarded as Real Sign of reproducing any person's Mind Images/Ideas/Thoughts in the forms of Predicate Verb Pattern and Predicate Verb Model as their adequate Mind Forms of the English-language discourse.

Key words: proposition predicate, predicate "atomic" verbs, homonym, predicate verb patterns, predicate verb models, infinitivization.

Problem statement. English Proposition Predicate has always been in the center of linguists'attention. A lot of linguistic discoveries and researches in the spheres of grammar, lexicology, semantics, pragmatics, cognitive linguistics involving Predicate have been made. Thus, the picture of functioning the English Proposition Predicate has been successfully determined and interpreted.
For instance, the nature of the semantic concept Proposition (the equivalent of the grammatical concept Sentence) containing its basic constituents - "Subject+Predicate" has been acknowledged as the basic integral explicit $(\mathrm{S}+\mathrm{P})$ unity, which is the major means of any human's reflection of the knowledge about the world in the English-language discource. But the notionPredicate in the frames of the English Proposition needs further clarifications and generalizations as the essential Proposition constituent or component creating any human's thought.

Predicate-it's Pattern and Model - is a real sign of revealing any sense and any meaning of any human's thought. Thus, the Subject of the work is the Proposition Predicate as the index of direct link between thinking and discourse in the process of recreating the reality with propositional signs/codes. The Object of the article is the description of the structural and semantic organization of the Proposition Predicate -Predicate Verb Patterns and Predicate Verb Models expressed by English three generalized "Atomic" Main Verbs "TO DO"/“TO BE"/“TO HAVE", which are used in their generalized meaning and sense in any kind of the English-language discourse Proposition, and which are absolutely meaningless at the same time being in the quality of Auxiliary Verbs.

Analysis of recent research and publications. The notion "Predicate" of English Proposition (Sentence) is widely investigated in modern linguistic researches such as "Codeblending with depicting signs" (R.M. Quadros, K Davidson, D. Lillo-Martin, 2019), "Building a single proposition from imagistic and categorical components"(K. Davidson, 2017), "Raising turn out in Late Modern English: The rise of a mirative predicate"(M.Serrano-Losada, 2017), "Complex predicateformation via voice incorporation"(S. Wurmbrand, 2016), "The development of the as-Secondary Predicate Construction: Constructionalization and internalization" (F. D'hoedt, H. Cuyckens, 2017) and some others. Basic Predicate Verb Models together with Predicate Complementation Structures are stated, but the Atomic Generalized Predicate Verb Patterns aren't deduced by contemporary scientists. According to the idea that a person cannot think a thought without the Predicate the concept the "Atomic" Generalized Predicate Main Verb Patterns is essential for understanding the Basic Sign of recreating and coding any human's thought in the Englishlanguage discourse.

The purpose of the article. The Purpose or Target of our research is to establish the Basic Sign of the English-language discourse Proposition, which is capable and adequate to recreate any human's thought.

Research. Predicate serves to assert something about its Subject denoting either an Action performed or undergone by the Subject or the State in which the Subject is/was/will be/etc. Predicate appears as the main principal basic link and it occupies the central position 
in any English Proposition according to its Word Order Algorithm: I Subject + II Predicate + III Complement (Object). According to most linguistic investigations all the Predicates fall under two main divisions: simple (verbal) predicates and compound (nominal/ verbal) ones. All the Simple and Compound Verbal Predicates denote Action or State; all the Compound Nominal Predicates denote State.

Predicate is regarded as a central element of a propositional structure (Proposition), it determines the structure of Proposition, and it holds within itself, contains the essence of state of affairs. $[1$, p. 120] And in this sense Predicate is defined as a propositional function, that is the form of judgement or Proposition, and this form is equivalent to the content of Predicate or Sentence. Thus, the concept of Predicate is defined as a special semantic essence of the English language, which is typified in the form of propositional functions (not in the form of vocabulary units) and the semantic structures of the Proposition (Sentence), which correspond to these functions. Predicate occupies a dominant position in the hierarchical system of "Predicate - Arguments". Predicate stands out as the peculiar constructive nucleus specifying its environment composition, which can consist of a certain number of its members (arguments). Arguments or non-Predicate signs include Subject and Complement (Object) expressed not only by nouns (common nouns and proper nouns) and substantival pronouns (substantival - from Latin substantivum - noun), but also by almost all the parts of speech in the English language. That's why Predicativity is interpreted as functional, not as a substantival category of words. [1, p. 77-78, 81]

The Proposition itself is understood as a certain element of thought, that is to say a relevant predicate, which "places" are filled with signs, and the mental (mind) process (the process of thinking) shown, displayed in the Propositions is that which psychologists call our inner speech. Thus, the Predicate or Predicate code (sign or symbol) may be regarded as a central, main, basic component of any English Proposition as the basic code recreating our thoughtsin the form of the Predicate expressing Predicativity, which is the key concept of reconstructing the human's thoughts by the variety of the appropriate codes.

In the English-language discourse any Predicate as the Code is expressed by the Main Verb first and foremost. The Verb is a word or phrase that tells what someone or something is, does, or experiences. There are two types of verbs: Main Verbs and Auxiliary Verbs.

According to linguistic deductions the most generalized picture of all the Predicate Main Verbs may be represented and reduced to two basic general lexical meanings: Action and State. In fact these generalized meanings: Action and State are presented or expressed by three generalized, basic, key Main verbs: "TO DO"/“TO BE"/“TO HAVE" that may be considered to be the basis of all the existing Real English Predicate Main Verbs constituting three basic generalized Predicate Verb Patterns: "TO DO" Predicate Verb Pattern/ "TO BE" Predicate Verb Pattern/ "TO HAVE” Predicate Verb Pattern.

Ahumancanneverthinkathought, which wouldn'thave Predicate and its referring element Subject. Thus, the fact of the availability of mental predicativity (a propositional structure) is irrefutable as "somebody's Action/State" or "Action/State of something". The concept "Action/State" goes back to the generalized, "latent" or "atomic" predicate verbs, which point out either the presence of connection ("copula"), or the most generalized and abstract type of connection, which isn't in need of its being concretized. The "atomic" predicate verbs don't call the concrete type of connection as the real verbs do that. The predicates of such type as "TO BE/TO DO/TO HAVE" can be regarded as "atomic" Predicate Main Verbs. [2, p. 119]

The generalized meanings (Action/State) of the mentioned generalized "Atomic" Predicate Main Verbs are as follows: 1. "TO DO" means Action: to speak, to know, to dance, to build, etc; 2. "TO BE" means State: to be young, to be polite, to be a dentist, to be happy, etc.; 3."TO HAVE" possesses or takes in two meanings: a) Action: to have a talk, to have dinner, to have a baby, etc.; b) State: to have a sister, to have a car, to have a cold, to have time, etc.

Since all the Subjects preceding Predicates strictly may be reduced to the set of the so-called "Atomic" Subjects "I"/"We"/"You"/"He"/"She"/ "It"/"They"/"There" (by analogy with the "Atomic" Predicate Verbs).

It is just the Predicate that reproduces, reflects any person's thoughts. According to the deduced generalized meanings of all the English Main Verbs - Action/State - it is essential to single out three English generalized Predicate Verb Patterns. They are as follows:

I "TO DO" Predicate Verb Pattern (Action) / II "TO BE" Predicate Verb Pattern (State) / III "TO HAVE" Predicate Verb Pattern (Action/State).

For instance, the presented above two deduced Predicate Verb Patterns "TO DO"/ "TO BE" are wide-spread, characteristic and typical for most legal terms in legal terminology. The most widely-used Predicate Verb Patterns ("TO DO"/“TO BE") as legal terms are as follows:

I "TO DO" (generalized meanings): to bring an action; to bring a case before the court; to bring a charge against smb.; to bring an accusation against; to enter a plea; to enter a protest; to enter the satisfaction; to take an affidavit; to take an appeal; to take the blame upon oneself; to take criminal proceedings; to take evidence; to take into custody; to take judicial notice of; to take legal advice; etc.

II "TO BE" - to be under an accusation of ...; to be against; to be accounted to be guilty; to be at the bar; to be under ban; to be bound to; to be charged with; to be convinced of; to be in council; to be out of court; to be in custody; to be guilty; to be innocent; to be liable; to be sued; to be tried at the bar; etc.

III All the meanings of the Main Verb "TO HAVE" are rather specific, definite, limited, and they are characteristic only to the Main Verb "TO HAVE" itself.

1. Have+Object=States. The meanings are as follows: possession; ownership; illnesses; family relationships: "He's got a power."; "She's got time."; "We've got a car."; "He has got a bad cold."; "He's got two sisters and three brothers.".

2. Have+Object=Actions. The meanings are various: to experience; to enjoy (of food, drink, etc.); to receive or obtain; to give birth to; to wish; etc.: "Do you have lectures every day?"; "Does he have a good time in Odessa?"; "Did you have a good holiday?"; "They are having a walk now."; "We were having a really interesting chat when John arrived."; "I have lunch at 12.30 most days."; "I'd like to have coffee.".

Complementation Structures include a lot of terms from different scientific fields and a lot of other expressions. The tendency of appearing Complementation Structures is rather progressive in modern English.

There is an important fact in English Grammar: the singled out three generalized "Atomic" Predicate Main Verbs ("TO DO"/“TO BE"/"TO HAVE") correspond to the same three Auxiliary 
Verbs: "DO", "BE", "HAVE". Auxiliary verbs have no lexical meanings. They are meaningless. They are called "helping" verbs and they are used together with the main verbs in order to "help" them to express particular grammatical functions and meanings (for instance, to make questions, negatives, or to form tenses, voices, etc.) There are two groups of Auxiliary Verbs. The first group includes Verb Forms "DO"/“BE"/"HAVE": 1) "DO" is used for making up Interrogative and Negative Propositions in the Present/ Past Simple Tenses: "We don't know the facts, but he doesn't notice that." "He didn't read the book, did he"; 2) "BE" is used in all the Propositions in the Continuous (Progressive) Tenses (Present, Past, Future) and Passive Voice: "She is dancing now." "She was crying at that moment." "She will be having a bath at 70 'clock a.m. tomorrow." He is known as a great scientist." "They will be invited to the party tomorrow"; 3) "HAVE" is used in: a) Propositions in all the Tenses of the aspect or group "Perfect" (the Perfect Tenses): "He has already passed his exams." "We have been discussing that for a week"; b) Propositions including Perfect Verb-Forms (Perfect Gerund/Perfect Infinitive): "I'm proud of having met such people" (Perfect Gerund). "You could have done it last week." (Perfect Infinitive). The second group of Auxiliary Verbs includes so-called "modal auxiliaries" (modal verbs): can/could/may/might/must/will/ would/shall/should/ought to/need.

The fact of full coincidence of three identical words ("DO"/“BE"/“HAVE") in the quality of the Verb (Main/Auxiliary) gives the possibility to confirm not only their "Atomic" status, but also their straightforward belonging to the category of Homonyms, that is quite natural for many English words as formal elements of the English-language discourse. Thus, the "Atomic" English Verbs corresponding to the words - Verb Forms "DO"/"BE"/"HAVE" are homonyms because they are both Main Verbs and Auxiliary Verbs.[3, p. 81-118; 4] These verbs constitute the essence of most Predicate Structures in the English-language discourse.

The fact of availability of verbs-homonyms in the structures of their Predicate Verb Patterns in cases of using one and the same form of the first predicate verb is obvious, for instance in the examples of using Subjunctive II independently of other clauses to express "advice": "had better do something", "had better not do something"; "preference": "would rather (sooner) do something", "would rather (sooner) have", "would rather (sooner) not do something"; "wish": "if only/somebody could do something" (could have done something/did something/had done something). For example: "You'd better, switch on the light." (advice); "I would rather stay at home." (preference); "If only I could help you!" (wish).

Thus, the Verb-Forms: "TO DO" (main/auxiliary); "TO BE" (main/auxiliary); "TO HAVE" (main/auxiliary); "Will" (modal verb/auxiliary verb denoting Future); "Would" (modal verb/ conditional/future-in-the-past) are homonyms but the meaning of any Proposition Verb Predicate as a Mind Form is absolutely clear: "What do you do?" ("What are you?" - old English) "He said, he would come tomorrow." "Would/Will you help me?" "He will arrive tomorrow." "He would do it if you asked him about it." "You may laugh if you will..." "I would have been glad if he had arrived yesterday." "I would call on him on my way home." "I asked him to give up smoking but he wouldn't." "He is a good student, isn't he?" "He is to go there this afternoon." "Does he do his morning exercises?"

The notion "homonym" is regarded as one and the same Verb Form either having absolutely completely different meanings
(Main Verb) or even being meaningless (Auxiliary Verb). Verbs Homonyms constitute the essence and the whole picture of all the appropriate Predicate Verb Models.

The above-mentioned fact gives the opportunity to establish and single out some definite Predicate Verb Models, which are characteristic of all the Proposition Verb Predicates. All the Predicate Verb Models have been defined according to the First Verb in the structure of any Predicate Verb Model.

Thus, Predicate Verb Patterns include three generalized Atomic Main Verbs: "TO DO"/"TO BE"/“TO HAVE". Predicate Verb Models involve Main Verbs and Auxiliary Verbs revealing some exact person's thought - so-called Mind Form - owing to its lexical and grammar representation.

The Predicate Verb Patterns and Models can be represented by the following Mind Forms:

1. "TO DO" Predicate Verb Pattern:

a) Main Verb "TO DO" (Predicate Verb Model): the first verb is Main Verb meaning Action (generalized "atomic" verb "TO DO"); all the propositions are affirmative sentences in the Present/Past Simple Tenses (Active Voice): "He listens to the news every day." "We played the guitar yesterday.";

b) Auxiliary Verb "TO DO" (Predicate Verb Model): the first auxiliary verb "do" is meaningless; all the propositions are interrogative and negative sentences in the Present/Past Simple Tenses (Active Voice): "Does he listen to the news every day?" "We didn't play the guitar yesterday.";

2. "TO BE" Predicate Verb Pattern:

a) Main Verb "TO BE" (Predicate Verb Model): the first verb is Main Verb meaning State (generalized "atomic" verb "TO BE");all the propositions are affirmative/interrogative/negative sentences in the Present/Past Simple Tenses (Active Voice): "She is a good dentist." "Is she a good dentist?" "She isn't a good dentist". "He was polite yesterday." "Was he polite yesterday?" "He wasn't polite yesterday."; all the constructions "There is/are (Present); There was/were (Past)": "There is some meat in the fridge." "There was no meat in the fridge yesterday"; all the Impersonal sentences (propositions) containing "TO BE": "It is winter now." "It was cold yesterday";all the propositions are Passive structures in all the tenses of using the predicates of the sentences in Passive Voice (except Perfect/Future Tenses): "He is admired by his friends." "The girl was loved." "They are blamed for having done such a thing";

b) Auxiliary Verb "TO BE" (Predicate Verb Model): the first auxiliary verb "TO BE" is meaningless; all the propositions are affirmative/interrogative/negative sentences in the Present/Past Continuous Tenses (Active Voice): "He is listening to the news now." "We were playing the guitar when he called us." "I am having a rest now."; all the propositions are in the Future Simple Tense (Pure Future and Present-Future expressed by the predicate construction "to be going to"): "He is going to join us in a week." "We are going to spend our holidays in Spain".

3. "TO HAVE" Predicate Verb Pattern (State):

a) Main Verb "TO HAVE" (Predicate Verb Model): the first verb is Main Verb meaning State (generalized "atomic" verb "TO HAVE"): meanings of illnesses/ownership/family relationships; the form "got" can be used only in the Present Simple Tense (British English); propositions are affirmative/interrogative/negative sentences in the Present Simple Tense (Active Voice): "He's got a cold/a car/a brother (Br.E.)". "Has he got a cold/a car/a brother? He hasn't got a cold/a car/a brother." Continuous Tenses are not used; 
b) Auxiliary Verb "TO DO" (Predicate Verb Model): the form "got" isn't used in the Past Tense (Active Voice) in British English and in the PresentPast Tenses (Active Voice) in American English; all the interrogative/negative sentences (propositions) are made up with the predicate first auxiliary verb "TO DO": "He has a cold (Am. E.)" "Does he have a cold?" "We doesn't have a cold." "We had a car last year." "Did we have a car last year?"'We didn't have a car last year."'"He had a lot of time yesterday." "Did he have a lot of time yesterday?" "He didn't have a lot of time yesterday".

4. "TO HAVE" Predicate Verb Pattern (Action):

a) Main Verb "TO HAVE" (Predicate Verb Model): the first verb is Main Verb meaning Action (generalized "atomic" verb "TO HAVE"); the form "got" isn't used; all the propositions are affirmative sentences in the Present/Past Simple Tenses (Active Voice): "She has breakfast every day." "We had a quarrel yesterday";

b) Auxiliary Verbs "TO DO"| "TO BE" (Predicate Verb Model): the first auxiliary verb "TO DO"/ "TO BE" is meaningless. All the interrogative/negative sentences (propositions) are made up with the predicate first auxiliary verb "TO DO" (Present/Past Simple Tense) or "TO BE" (all the Continuous Tenses): "Does she have breakfast every day? She doesn't have breakfast every day." "Did we have a quarrel yesterday? We didn't have a quarrel yesterday." "She is having a baby now." "We were having a talk at that moment" "He will be having dinner at 50 'clock tomorrow".

5. "TO DO"/ "TO BE" Predicate Verb Pattern:

a) Auxiliary Verb "TO HAVE" (Predicate Verb Model): the first auxiliary verb "TO HAVE" is meaningless; all the propositions are affirmative/interrogative/negative sentences in all the Perfect Tenses (Active/Passive Voices) except Future Perfect: "He has just left. Has he just left? He hasn't just left." "She has been known for a long time. Has she been known for a long time? She hasn't been known for a long time. I had been asked about that before";

6. "TO DO" / "TO BE" / "TO HAVE" Predicate Verb Pattern:

a) Auxiliary Verbs/Modal Auxiliaries (Predicate Verb Model): the predicate first auxiliary verb is a modal verb, which is used as a helping verb with the other main verb to change its meaning in some way. The verbs "can", "could", "may", "might", "must", "ought to", "shall" "should", "will", "would", "dare", "need" are called modal verbs. They denote neither Actions nor States, but only the attitude of the speaker towards the Action or State expressed by the infinitive, which always follows the modal verb. Thus, a modal verb is never used alone as the predicate of a sentence (proposition), but it is always combined with an Indefinite/Perfect infinitive forming a modal compound verbal predicate. The infinitive expresses the main idea of the predication, the modal verb has only modal function, that is, it indicates that the action denoted by the infinitive is considered as desirable, possible, doubtful, etc. The infinitive which is associated with the modal verb is used without the particle "to", except the modal verb "ought to": "I can translate this text." (Mental ability); "You must write the letter at once." (Obligation); "It must be very late." (Supposition); "You ought to help him." (Admonition); "You could have done it yesterday." (Possibility) = "There was a possibility but you didn't do it yesterday." Some modal verbs ("can", "may", "must") can be followed by a) Continuous Infinitive: "Hurry up! They must be waiting for us already."; b) Perfect Continuous Infinitive: "I must have been reading for 3 hours." Modal verbs can be used with the forms of the Infinitive in Passive Voice: "The letter should be sent off at once."; all the propositions are affirmative/interrogative/negative sentences can be made up in Present/Past/Future. The first element (modal verb) of the predicate structure depends on the meaning of the modal verb itself, for instance one of the meanings of "can" is ability: "He can translate this text (Present/Future) Can he translate this text? (Present/Future)" "He cannot (can't) translate this text (Present/ Future)"; "He could translate this text (Past)"; "Could he translate this text? (Past)"; "He couldn't translate this text." (Past);

b) Auxiliary Verb "Will"/"Would" (Predicate Verb Model): the predicate first auxiliary verb is "will" (homonym of the modal verb "will"), which is used in the Future Simple Tense (Pure Future) with all the persons ("shall" with the first person singular is old English). All the propositions are affirmative/interrogative/negative sentences in all the Future Tenses Aspects (Simple/Continuous/ Perfect): "He will tell the truth. Will he tell the truth? He won't tell the truth." (Future Simple) "This time tomorrow he will be telling the truth." (Future Continuous) "He will have told the truth by Tuesday." (Future Perfect) "He will have been telling the truth for 5 years this summer." (Future Perfect Continuous) "There will be some questions tomorrow. There will be fish in the fridge tomorrow." (The constructions "There is/are") "It will be spring in a month." (Impersonal sentences); the predicate first auxiliary verb is "would" (homonym of the modal verb "would"), which is used in the Futurein-the-Past. In English the tense of the verb in a subordinate clause (mainly object clause) depends on that of the verb in the principal clause. This adjustment of the tense of the subordinate clause to the tense of the principal clause is called the Sequence of Tenses. A past tense in the principal clause must be followed by a past tense in the subordinate clause, for instance Future-in-the-Past, FuturePerfect-in-the-Past: "She was sure that they would come./He said that he would have been a lawyer by next year";

c) Modal Equivalent (Predicate Verb Model): the predicate first verb involves modal equivalents "dare"/"need"/"be to"/"used to"/"be able to"/"be going to"/"have to". Modal Equivalent is another example of the fact that the "atomic" verbs "TO DO"/"TO BE"/"TO HAVE" are homonyms: "He is to go to Kyiv." (necessity according to the plan); "He had to post the document yesterday." (necessity in the Past tense); "Do you have to go? Have you to go?" (necessity in the Present tense); "Did you used to work there? Used you to work there?" ("used" in the Past tense only to show that something happened always or regularly); the predicate first verb is Conditional "would" (homonym of modal verb "would" and the form "would" in the Future-in-the-Past) in the Main clauses/Subjunctive II two forms: 1) "non-perfect» (were, went) and 2) "perfect" (had been, had gone) in the Subordinate clauses in the Conditional sentences of the second and third types representing the action/state as unreal, as contrary to reality (The Subjunctive Mood): "If he called I would (should) be glad." (non-Perfect forms: general time)" "If he had called I had been glad." (Perfect forms, Past time)"I would have told you if I'd realized you didn't know." (Perfect forms, Past time)"You'd be invited to more parties if you smiled more often." (Passive forms: general time).

Note: the Subjunctive I forms are: a) to be (present tense): I be, you be, he be, we be, they be; b) other verbs (past tense): I were, you were, he were, we were, they were.

The Subjunctive I is not very common in modern British English/American English, and is used mostly in formal style. The ideas of talking about events which are not certain to happen which we hope will happen, or imagine might happen, or want to happen are usually expressed in other ways. 
All the examples of the Predicate Main Verbs shown above correspond to the combination of words - one of the formal elements of the English-language discourse hierarchy. The represented word combinations go back in their forms to one of the five Verb forms the Infinitive. The Infinitive Structure/Construction is considered to be the combination of words: a) the Finite Verb Infinitive particle "to" plus Base Form of the Verb: "to issue", "to serve", etc.; b) the Phrasal Verb Infinitive - particle "to" plus Base Form of the Phrasal Verb plus an Adverb and/or (a) Preposition(s): "to set down/aside", "to be against", "to run out"; "to use up", "to give up", "to look after", "to put up with", etc.; c) the Complementation Infinitive Structure $(\mathrm{V}+\mathrm{C})$ - particle "to" plus Base Form of the Verb plus Complement (Object): "to take criminal proceeding", "to enter a protest", etc. Complementation Structure is a result of merging the Predicate with its Complement (Object) strictly following it into the Integral Unity having its appropriate, common, indivisible meaning: "to do good"; "to do harm"; "to do business"; "to make an offer"; "to make arrangements"; "to make a phone call"; etc. [5, p. 170].

Any Infinitive Structure could be a potential Predicate Structure (in all its possible Patterns and Models) of any Proposition. As potential explicit Predicate all the Infinitive Structures mentioned above may be called Infinitivization. Thus, any Infinitivization can be explicit Predicate Verb Pattern/Model of any possible Propozition in the English-language discourse.

Owing to the fact of existing the set of implicit "Atomic" Subjects in any human's consciousness, according to their availability any appropriate explicit Predicate Verb Structure (Pattern and Model) may be regarded as Implicit Proposition Structure of any appropriate Explicit Proposition Structure (Subject plus Predicate). Thus, any Infinitivization could be easily transformed into a Proposition (Sentence) recreating any human's Thought/Idea/Image.

For example, "to be found guilty" (He was found guilty last year.); "to bring a case before the court" (We have just brought a case before the court.); "to take criminal proceedings" (They will take criminal proceedings next month.)

Infinitivizations represent the basic database of the Englishlanguage discourse. Any Infinitivization in the quality of any potential Predicate is English Implicit Propositional Structure Sign/Code reflecting our Thought/Idea/Image.

Thus, Predicate Structure is the essential part of any English Proposition (Subject+Predicate Pattern). Predicate Structure is expressed by certain Predicate Verb Patterns and Predicate Verb Models.

The Basis of all the Predicate Verb Patterns and Models is the notion of Infinitivization.

It is just the Predicate, which is the Proposition summit and the main Proposition Code, the minimum Proposition Sign of close, direct, spontaneous connection between the process of thinking and discourse. Predicate is the backbone of any Proposition (Sentence). The quality of being the Backbone is most essential for Predicate. That means that Predicate is the major constructive element, the essence of any human's Thought, Idea and more precisely any person's Code or Real Sign recreating our Ideas, namely our Mind Images.

Conclusions. The Basic Code/Sign of recreating any human's Thought (Idea) is Proposition corresponding to Sentence as a central formal element of the English-language discourse hierarchy. But potential new Propositions may be easily constructed on the basis of their Predicate Main Verb Patterns ("TO DO"/ "TO BE"/"TO HAVE") with the help of any Subject in any human's consciousness since nobody can think a thought without Predicate and its Referring Element. We suggest the idea that in general a referring element is the Subject (any person or thing). The stated fact about Predicate may be confirmed by the availability of the Impersonal Sentences and the Constructions "There is/are", where their Subjects such as "It" and "There" are meaningless. It's just the Predicate Verb Pattern/Model that is the actual minimum Code or Sign reproducing any human's thought. Any Predicate Verb Pattern/Model in isolation corresponds to the Combination of Words, which is known as so-called "Infinitivization" going back to the Infinitive Construction in its simple and compound forms, that is, Verb, Phrasal Verb and Complementation Structure $(V+C)$ as the example of merging Predicate with its Complement (Object) into the indivisible integral semantic unity. The Infinitivization may be regarded as a "nucleus" of the potential Predicate Verb Pattern /Model of the new potential Proposition. Such constructions as Infinitivizations - Combinations of Words - are widely presented in the sphere of terminology and they represent the main part of its enormous database. Any term in the quality of Infinitivization in different scientific and social spheres (the potential Predicate) corresponds to a combination of words as the minimum formal element of the English-language discourse hierarchy, which is capable to express any person's thought.

Thus, Predicate is the minimum, the most important and valid Code/Mind Form - the Basic Real Sign recreating and verbalizing our Ideas, our Mind Images and our Thoughts.

\section{References:}

1. Nikitin M. Fundamentals of the linguistic theory of meaning, [Osnovy lingvisticheskoj teorii znachenija]. Moscow : Higher education. Sch., 1998. $165 \mathrm{p}$.

2. Kubrjakova E., Serebrennikov B. Nominative aspect of speech activity. Moscow : Science, 1986. 156 p.

3. Boyarskaya E., Zabotkina V. "Development of the methodology of cognitive analysis of a multi-valued word", Methods of cognitive analysis of word semantics: computer-hull approach. Moscow : Languages of Slavic Culture. 2015. P. 81-118.

4. Cameron D., Vovk Yu. Spoken discourse. Interpretations and practices. Trans. from Eng. [Razgovornyj discurs. Interpretacii i practiki]. H. : publishing house "Humanitarian Center", 2015. 316 p.

5. Dombrovan, T. Language in the context of synergetics, Odessa : KP OGT, 2013. $345 \mathrm{p}$.

\section{Маслова С. Б. Предикатний знак англійської пропозиції}

Анотація. У статті наведено результати лінгвістичного аналізу предикату англійської пропозиції, який розкриває іiі семантичні значення у якості основного концепту експліцитної пропозиції англомовного дискурсу, а також у якості найбільш адекватного та спроможного знаку кодування людської думки / ідеї / образу. Дедуктивні, індуктивні та евристичні методи дослідження призвели до виведення трьох ключових базових, узагальнених за їх значеннями, головних дієслів "TO DO"/“TO BE"/“TO HAVE", які є основою всіх паттернів/моделей дієслова предикату. Евристика (грец. Heurisko - знаходити, відкривати) - це наука, яка вивчає творчу діяльність та методи, що використовуються в процесі розкриття нових ідей та у викладанні. Евристичні методи дозволяють прискорити процес вирішення проблеми, оскільки метою евристики 
є побудова моделей процесу розв'язання нової задачі. Узагальненими значеннями всіх головних дієслів є Дія та Стан: "TO DO" означає Дію; “ТО BE" - Стан, а дієслово “TO HAVE” має два значення: Дія/Стан. Саме паттерн/ модель дієслова предикату, що лежить в основі будь-якої пропозиції (речення), і $є$ основним кодом для відтворення думки/ідеї/образу будь-якої людини. У статті розкривається фактичний мінімальний основний конструктивний знак кодування думки будь-якої людини, яким є експліцитний паттерн дієслова предикату та модель дієслова предикату у відповідності до ідеї, що людина не здатна утворити думку без предиката. Цей мінімальний код відповідає словосполученню як одному 3 формальних елементів ієрархії англомовного дискурсу. Будь-який паттерн дієслова предикату та будь-яка модель дієслова предикату побудовані на основі інфінітивної конструкції, відомої під назвою «інфінітивізація». Інфінітивізація звертається до інфінітиву в його простих та складних формах (дієслово, фразове дієслово та комплементаційна структура) і може розглядатися як «ядро» потенційного паттерну дієслова предикату та моделі дієслова предикату потенційної експліцитної пропозиції. Наприклад, такі конструкції, як інфінітивізація, широко представлені в юридичній термінології та є основною частиною її величезної бази даних. Будь-який юридичний термін у якості інфінітивізації відповідає словосполученню як мінімальному знаку/коду англомовного дискурсу. Інфінітивізація може розглядатися як реальний знак відтворення образів/думок/ідей будьякої людини. Адекватною формою думки англомовного дискурсу є паттерн дієслова предикату та модель дієслова предикату.

Ключові слова: предикат пропозиції, «атомарні» дієслова предикату, омонім, паттерни дієслів предикату, моделі дієслів предикату, інфінітивізація. 